\title{
ANALISIS FAKTOR-FAKTOR YANG BERHUBUNGAN DENGAN PEMILIHAN KB METODE OPERASI WANITA (MOW) PADA PASANGAN USIA SUBUR DI DESA WINONG KECAMATAN PATI KABUPATEN PATI
}

\author{
Erika Fuadsanah ${ }^{1)}$, Sri Hadi Sulistiyaningsih ${ }^{2)}$,Yuli Irnawati ${ }^{3)}$. \\ 1) Stikes Bakti Utama Pati D III Midwifery Study Program \\ ${ }^{2)}$ Stikes Bakti Utama Pati S1 Midwifery Study Program \\ 3) Stikes Bakti Utama Pati D III Midwifery Study Program \\ E-mail: erikafuadsanah@gmail.com ${ }^{1)}$, mahira.hsp@gmail.com ${ }^{2)}$ yuliirnawati30@gmail.com ${ }^{3)}$
}

\begin{abstract}
ABSTRAK
Kontrasepsi mantap pada wanita adalah setiap tindakan pada kedua saluran telur yang mengakibatkan orang yang bersangkutan tidak akan mendapatkan keturunan lagi dan kontrasepsi ini untuk jangka panjang (Sri Handayani, 2010). Berdasarkan survey awal yang dilakukan kepada 10 responden didapatkan hasil bahwa ada 5 responden menggunakan KB MOW dikarenakan usia diatas 30 tahun, mempunyai anak diatas 2, dan mendapatkan dukungan dari suami. 2 responden menggunakan KB implant dan 3 responden menggunakan KB suntik 3 bulan.

Jenis penelitian yang digunakan analitik korelasi dengan pedekatan cross sectional. populasi dalam penelitian ini adalah seluruh akseptor KB MOW sebanyak 94. Sampel sebanyak 33 responden. Teknik sampling menggunakan Stratified Random Sampling. Uji statisik yang digunakan adalah Chi Square.

Hasil penelitian menunjukkan sebagian besar responden memilih menggunakan KB MOW yaitu usia $\geq 30$ tahun sebanyak 30 orang $(90,9 \%)$, paritas $\geq 2$ sebanyak $32(97 \%)$, dan mendapatkan dukungan suami mendukung sebanyak 27 orang $(81,8 \%)$. Tidak ada hubungan antara usia dengan pemilihan KB MOW diperoleh hasil $x^{2}=0,112$ dan $p$ value $=1,000$, paritas dengan pemilihan KB MOW diperoleh hasil $x^{2}=0,760$ dan $p$ value $=1,000$, dan dukungan suami dengan pemilihan $\mathrm{KB}$ MOW diperoleh hasil $x^{2}=3,243$ dan $p$ value $=1,000$.

Diharapkan bagi tenaga kesehatan untuk dapat meningkatkan pemberian konseling dan informasi mengenai metode kontrasepsi jangka panjang (MKJP) khususnya KB MOW.
\end{abstract}

Kata Kunci : Kontrasepsi Mantap, Usia, Paritas, Dukungan Suami, Pemilihan KB MOW

\section{ABSTRACT}

Steady contraceptives in women are any action on both the ovaries that result in the person in question will not get any more offspring and these contraceptives for the long term (Sri Handayani, 2010). Based on the initial survey conducted to 10 respondents obtained the result that the re are 5 respondents using $K B M O W$ due to age above 30 years, have children above 2 , and get support from the husband. 2 respondents used an KB implant and 3 respondents using a 3 -month injectable KB.

The type of research used in analytic correlation with Pedekatan cross sectional. The population in the study was all KB MOW acceptors as much as 94. Sample of 33 respondents. Sampling techniques using Stratified Random Sampling. The static test used was Chi Square.

The results showed that most respondents opted to use $K B M O W$, which is $\geq 30$ years of age 30 people (90.9\%), parity of $\geq 2$ as much as 32 (97\%), and support for supporting a total of 27 people $(81.8 \%)$. No relationship between ages with the selection of the SSMOW obtained $x^{\wedge} 2=0.112$ and $P$ value $=1.000$, parity with the selection of the result of $K B M O W x^{\wedge} 2=0.760$ and $P$ value $=1.000$, and husband's support with the selection of R MOW obtained $x^{\wedge} 2=3.243$ and $P$ value $=1.000$.

It is expected for health workers to be able to improve counseling and information on long term methods of contraception in particular KB MOW.

Keywords: steady contraceptives, age, parity, husband support, election KB MOW 


\section{PENDAHULUAN}

Kontrasepsi adalah upaya untuk mencegah terjadinya kehamilan upaya itu dapat bersifat sementara, dapat pula bersifat permanen. Penggunaan kontrasepsi merupakan salah satu variabel yang mempengaruhi fertilitas. Keluarga berencana $(\mathrm{KB})$ intervensi kesehatan yang cost effective dan menyelamatkan nyawa perempuan dan anak. Keluarga berencana merupakan suatu program pemerintah yang antara kebutuhan dan jumlah penduduk. Peserta keluarga berencana (KB) adalah pasangan usia subur dimana salah satunya menggunakan cara atau alat kontrasepsi untuk tujuan pencegahan kehamilan baik melalui program KB maupun non-program KB (Noviawati, 2011).

Di Pati jumlah PUS nya yaitu sebanyak 271.084. Peserta KB aktif di kabupaten pati yaitu yang paling banyak yaitu KB Suntik yaitu sebanyak (61\%), PIL sebanyak $(22,9 \%)$, Implant $(7,3 \%)$, Kondom $(3,8 \%)$, IUD (3,3\%), MOW (1,6\%), dan MOW sebanyak $(0,1 \%)$ dari data tersebut menandakan bahwa di daerah Pati PUS yang menggunakan MOW masih rendah (Dinas Kesehatan Kabupaten Pati, 2016).

Factor-Faktor pemilihan KB MOW ada 8: (1) Tingkat Pendidikan. (2) Pengetahuan. (3) Agama. (4) Status Sosial Ekonomi dan Tingkat Kesejahteraan. (5) Panutan (Role Model). (6) Usia. (7) Paritas. (8) Dukungan Suami. Umur atau usia adalah satuan waktu yang mengukur waktu keberadaan suatu benda atau makhluk, baik yang hidup maupun yang mati (Depkes, 2009). Usia yang di tetapkan untuk melakukan sterilisasi pada wanita berumur 22 tahun dengan 5 orang anak. Untuk batasan umur termuda pada usia 25 tahun. 25-30 tahun dengan 4 anak hidup. 30-35 tahun dengan 3 anak hidup, dan diatas 35 tahun dengan 2 anak hidup (Depkes, RI 2009).
Paritas adalah jumlah kehamilan yang menghasilkan janin yang mampu hidup diluar rahim (28 minggu) (JHPIEGO, 2008). Sedangkan menurut Manuaba (2008), Paritas adalah banyaknya kelahiran hidup yang dipunyai oleh seorang wanita (BKKBN, 2006)

Dukungan Suami adalah kemampuan Suami memandang bahwa orang yang bersifat mendukung selalu siap memberikan dukungan dan bantuan bila diperlukan (Efendi, 2009). Dukungan suami adalah kemampuan suami memberikan penguatan satu sama lain juga kemampuan mencipatakan suasana saling memiliki (Setiadi, 2008). Bentuk dukungan suami yang dapat diberikan kepada istri yaitu seperti dukungan emosional, dukungan penghargaan atau penilaian, dukungan instrumental, dan dukungan informatif (Friedman, 1998).

Berdasarkan hasil penelitian oleh Zulfajri rahman dkk (2017) dengan judul "Faktor-faktor yang berhubungan dengan penggunaan KB MOW" bahwa tidak ada hubungan antara pengetahuan dengan penggunaan kontrasepsi MOW dengan nilai $\mathrm{p}=0,981 \quad(\mathrm{p}=0,05)$, tidak ada hubungan pendidikan dengan penggunaan kontrasepsi MOW dengan nilai $\mathrm{p}=0,064(\mathrm{p}=0,05)$, ada hubungan antara dukungan suami dengan penggunaan kontrasepsi MOW dengan nilai $\mathrm{p}=0,009(\mathrm{p}=0,05)$.

\section{METODE PENELITIAN}

Jenis penelitian yang digunakan analitik korelasi dengan pedekatan cross sectional. populasi dalam penelitian ini adalah seluruh akseptor KB MOW sebanyak 94. Sampel sebanyak 33 responden. Teknik sampling menggunakan Stratified Random Sampling. Uji statisik yang digunakan adalah Chi Square.

\section{HASIL DAN PEMBAHASAN}

Hasil

Tabel 1. Faktor-Faktor Pemilihan KB

Faktor Paritas

\begin{tabular}{|c|c|c|}
\hline$<2$ & 1 & 3,0 \\
\hline$\geq 2$ & 32 & 97,0 \\
\hline Total & 33 & $100 \%$ \\
\hline
\end{tabular}




\begin{tabular}{l|c|c}
\hline Mendukung & 27 & 81,8 \\
\hline Kurang Mendukung & 4 & 12,1 \\
\hline Tidak Mendukung & 2 & 6,1 \\
\hline Total & 33 & $100 \%$ \\
\hline
\end{tabular}

Faktor Pemilihan KB

\begin{tabular}{l|c|l|lc}
\hline$<3$ tahun & 14 & 42,4 \\
\hline \multicolumn{5}{l}{} \\
\hline Faktor Usia & $\mathrm{F}$ & \multicolumn{3}{l}{ Presentase (\%) } \\
\hline$<30$ Tahun & 3 & $9,1 \%$ & \\
$\geq 30$ Tahun & 30 & $90,9 \%$ & \\
\hline Total & 33 & $100 \%$ & 57,6 \\
\hline$\geq 3$ tahun & 19 & $100 \%$ \\
\hline Total & 33 & \\
\hline
\end{tabular}

Berdasarkan tabel 1. Dapat diketahui bahwa usia ibu < 30 tahun sebanyak 3 orang $(9,1 \%)$ dan usia ibu $\geq 30$ tahun sebanyak 30 orang (90,9\%). Jumlah paritas < 2 sebanyak 1 orang $(3,0 \%)$ dan $\geq 2$ sebanyak 32 orang $(97,0 \%)$. Suami yang mendukung sebanyak

Tabel 2. Hubungan Faktor-fa

\begin{tabular}{c|c|c|c|c|c|c|c|c|c}
\multicolumn{8}{c}{ Tabel 2. Hubungan Faktor-faktor Dengan Pemilihan KB MOW } \\
\hline $\begin{array}{c}\text { Fakt } \\
\text { or }\end{array}$ & \multicolumn{2}{|c|}{ Pemilihan Alat Kontrasepsi } & Total & $\%$ & $\chi^{2}$ & \multirow{2}{*}{ P value } \\
\cline { 2 - 7 } & $\mathrm{F}$ & $\%$ & $\mathrm{~F}$ & $\%$ & \multicolumn{7}{c}{ Usia } \\
\hline $\begin{array}{c}<30 \\
\text { thn }\end{array}$ & 1 & 3,0 & 2 & 6,1 & 3 & 9,1 & 0,112 & 1.000 \\
\hline $\begin{array}{c}\geq 30 \\
\text { thn }\end{array}$ & 13 & 39,4 & 17 & 51,5 & 30 & 90,9 & & \\
\hline Total & 14 & 42,4 & 19 & 57,6 & 33 & 100 & & \\
\hline
\end{tabular}

Parit

\begin{tabular}{|c|c|c|c|c|c|c|}
\hline$<2$ & 0 & 0 & 1 & 3,0 & 1 & 3,0 \\
\hline$\geq 2$ & 14 & 42,4 & 18 & 54,5 & 32 & 97,0 \\
\hline Total & 14 & 42,4 & 19 & 57,6 & 33 & 100 \\
\hline
\end{tabular}

27 orang $(81,8 \%)$, kurang mendukung sebanyak 4 orang $(12,1 \%)$, dan Tidak mendukung sebanyak 2 orang $(6,1 \%)$. Dan Pemilihan KB MOW < 3 tahun sebanyak 14 orang $(42,4 \%)$ dan $\geq 3$ tahun sebanyak 19 $(57,6 \%)$.

Berdasarkan tabel 2. Dapat diketahui bahwa usia ibu usianya kurang dari 30 tahun yang memilih menggunakan KB MOW < 3 tahun yaitu sebanyak 1 responden $(3,0 \%)$ dan $\geq 3$ tahun sebanyak 2 responden $(6,1 \%)$. Sedangkan responden yang usianya lebih dari 30 tahun yang menggunakan KB MOW $<3$ tahun yaitu sebanyak 13 responden $(39,4 \%)$ dan yang menggunakan KB MOW $\geq 3$ tahun sebanyak 17 responden $(51,5 \%)$

paritasnya kurang dari 2 yang memilih menggunakan KB MOW yaitu Pengguna $\geq$ 3 tahun sebanyak 1 responden $(3,0 \%)$. Sedangkan responden yang paritasnya lebih dari 2 memilih menggunakan KB MOW dengan pengguna $<3$ tahun yaitu sebanyak \begin{tabular}{l|l}
0,760 & 1.000
\end{tabular}

14 responden $(42,4 \%)$ dan yang pengguna $\geq$ 3 tahun sebanyak 18 responden $(54,5 \%)$.

Dukungan Suaminya Mendukung menggunakan KB MOW < 3 tahun yaitu sebanyak 11 responden $(33,3 \%)$ dan Pengguna $\mathrm{KB} \geq 3$ tahun sebanyak 16 responden $(48,5 \%)$. Sedangkan responden yang mendapatkan Dukungan Suaminya Kurang Mendukung menggunakan KB MOW $\geq 3$ tahun yaitu sebanyak 2 responden $(7,0 \%)$ dan $<3$ tahun sebanyak 2 responden $(7,0 \%)$. Dan responden yang mendapatkan Dukungan Suaminya Tidak Mendukung menggunakan KB MOW $<3$ tahun sebanyak 1 responden $(2,1 \%)$ dan $\geq 3$ tahun sebanyak 1 responden $(2,1 \%)$. 


\section{PEMBAHASAN}

Setelah dilakukan pengujian ternyata terdapat nilai $\mathrm{E}<5$ sehingga untuk menentukan hasil uji statistika harus menggunakan fisher's exact test, diperoleh hasil $p$ value $=1.000$ sehingga secara statistik dapat disimpulkan bahwa tidak ada hubungan antara usia dengan pemilihan KB MOW di Desa Winong Kecamatan Pati Kabupaten Pati.

Setelah dilakukan pengujian ternyata terdapat nilai $\mathrm{E}<5$ sehingga untuk menentukan hasil uji statistika harus menggunakan fisher's exact test, diperoleh hasil $p$ value $=1.000$ sehingga secara statistik dapat disimpulkan bahwa tidak ada hubungan antara paritas dengan pemilihan KB MOW di Desa Winong Kecamatan Pati Kabupaten Pati.

Setelah dilakukan pengujian ternyata terdapat nilai $\mathrm{E}<5$ sehingga untuk menentukan hasil uji statistika harus menggunakan fisher's exact test, diperoleh hasil $p$ value $=1.000$ sehingga secara statistik dapat disimpulkan bahwa tidak ada hubungan antara Dukungan Suami dengan pemilihan KB MOW di Desa Winong Kecamatan Pati Kabupaten Pati.

\section{Kesimpulan}

Dari sebagian ibu yang menggunakan KB MOW yaitu usia sudah $\geq 30$ tahun, paritas $\geq 2$, dan ibu yang memilih menggunakan KB MOW yaitu sudah mendapatkan dukungan dari suami.

Diharapkan tenaga kesehatan khusunya bagian penyuluh KB yang ada di wilayah khususnya di Desa Winong agar lebih aktif lagi dalam pemberian informasi mengenai alat kontrasepsi MOW sebagai alat kontrasepsi mantap yang dapat digunakan untuk mengakhiri kehamilan.

\section{DAFTAR PUSTAKA}

1. Amirin, T. 2011. Populasi Dan Sampel Penelitian 4: Ukuran Sampel Rumus Slovin. Jakarta: Erlangga.

2. Arikunto, S. 2013. Prosedur Penelitian: Suatu Pendekatan Praktik. Jakarta: Rineka Cipta.
3. Hidayat, A. Aziz Alimul. 2014. Metode Penitian Kebidanan dan Teknik Analisis Data. Jakarta: Salemba Medika.

4. BKKBN. 2009. Keluarga Berencana Dan Kesehatan Reproduksi. http://www.bkkbn.go.id/. Diakses pada tgl 19 November 2018.

5. Handayani, Sri. 2010. Buku Ajar Keluarga Berencana. Yogyakarta: Pustaka Rihama.

6. Hartanto, Hanafi. 2015. Keluarga Berencana dan Kontrasepsi. Jakarta: CV Muliasari.

7. Hidayati, Ratna. 2009. Metode dan Teknik Penggunaan Alat Kontrasepsi. Jakarta: Salemba Medika.

8. Indriyani, Diyan dan Asmuji. 2014. Buku Ajar Keperawatan Maternitas. Yogyakarta: Ar-Ruzz Media.

9. Indrayani. 2014. Vasektomi Tindakan Sederhana dan Menguntungkan Bagi Pria. Jakarta: CV. Trans Info Media

10. Notoadmodjo, Soekidjo. 2010. Metodologi Penelitian Kesehatan. Jakarta:PT Asdi Mahasatya.

11. Notoadmodjo, Soekidjo. 2012. Metodologi Penelitian Kesehatan. Jakarta: PT Asdi Mahasatya.

12. Rahman, Zulfajri dkk. 2017. Faktorfaktor Yang Berhubungan Dengan Penggunaan Kontrasepsi Metode Operasi Wanita, Vol 7, Nomor 2, Hal 153-157, http://repository.lppm.unila.ac.id/2485/1 /6.1-Chania Forcepta.pdf, diakses pada tanggal 19 november 2018 jam 18.25 WIB.

13. Rodiani dan Chania Forcepta. 2017. Faktor-faktor Penggunaan Alat Kontrasepsi Metode Operasi Wanita (MOW) Pada Pasangan Usia Subur. Vol 6, Nomor 1, Hal 11-17, https://media.neliti.com/media/publicati ons/223812-the-factors-related-to-theapplication-o.pdf, diakses pada tanggal 19 november 2018 jam 19.00 WIB.

14. Sugiyono. 2009. Metode Penelitian Kuantitatif Kualitatif dan $R \& D$. Bandung: CV Alfabeta. 